\title{
Ornamentation of dermal bones of Placodermi from the Lower Devonian of Morocco as a measure of biodiversity
}

\author{
Mateusz Antczak ${ }^{1 *}$, Błażej Berkowski ${ }^{1}$ \\ ${ }^{1}$ Adam Mickiewicz University, Faculty of Geographical and Geological Sciences, Institute of Geology, Department of \\ Palaeontology and Stratigraphy, Krygowskiego 12, 61-680 Poznań, Poland \\ * corresponding author, e-mail: mateusz.antczak@amu.edu.pl
}

\begin{abstract}
Dermal bones are formed early during growth and thus constitute an important tool in studies of ontogenetic and evolutionary changes amongst early vertebrates. Ornamentation of dermal bones of terrestrial vertebrates is often used as a taxonomic tool, for instance in Aetosauria, extant lungfishes (Dipnoi) and ray-finned fishes (Actinopterygii), for which it have been proved to be of use in differentiating specimens to species level. However, it has not been utilised to the same extent in placoderms. Several features of the ornamentation of Early Devonian placoderms from Hamar Laghdad (Morocco) were examined using both optical and scanning electron microscopy to determine whether it is possible to distinguish armoured Palaeozoic fishes. Four distinct morphotypes, based on ornamentation of dermal bones, are differentiated. These distinct types of ornamentation may be the result of either different location of dermal plates on the body or of ontogenetic (intraspecific) and/or interspecific variation.
\end{abstract}

Keywords: Arthrodira, interspecific variation, ontogeny, fishes, North Africa

\section{Introduction}

Dermal bones, or membranous bones, form without a chondral stage; in extant fish taxa these include the bones of the cranium and pectoral girdles. In fossil taxa, dermal bone comprises the external plates of the head and trunk shield in jawless fishes and stem gnathostomes, the Placodermi. In extant taxa, the commonest dermal bones occur in the form of scale covering of fish and chondrichthyans. To date, due to their small size and fragility, single fish scales have only rarely been used as a systematic tool at the species level by biologists (Patterson et al., 2002; Kaur \& Dua, 2004; Esmaeili \& Gholami, 2011). In extinct taxa, palaeontologists have used scales of palaeoniscoids to differentiate both between species and ontogenetic stages (Trinajstic, 1999); acanthodians are almost exclusively known by scale taxa (Brazeau \& Friedman, 2015), as are many sharks (e.g., Martin, 2009).

Palaeozoic (Silurian-Devonian) Placodermi differ from modern fishes in that their heads and trunks were covered by armour consisting of bony plates. Placoderm remains are known from Asia, Australia, Africa, Europe and South and North America (Denison, 1978; Janvier et al., 1997; Szrek, 2006; Janvier, 2007; Long \& Trinajstic, 2010; Long \& Daeschler, 2013; Olive et al., 2016). Among these bony plates, scales, tooth plates and even elements of the axial skeleton of placoderms are represented (Ritchie, 2005; Trinajstic \& Hazelton, 2007; Johanson \& Trinajstic, 2014), but the plates are most of- 



Fig. 1. Dermal bone ornamentation: A - Phyllolepida (HL3/1p/1); B - Arthrodira (HL3/1p/2).

ten encountered remains of armoured fishes, as a result of which they are diagnostic features not only of several orders of Placodermi (representatives of different orders may possess different patterns of sculpture; see Fig. 1), but also of particular genera or species (Szrek, 2012), e.g., Driscollaspis (Rücklin et al., 2015). Species designations are based on scales, tooth plates, complete specimens or, occasionally, on single plates, but isolated plate fragments make descriptions difficult.

In modern fishes it is possible to differentiate species on the basis of microscopic analysis of single scales that appear identical on a macroscale (Kaur \& Dua, 2004; Esmaeili \& Gholami, 2011; Kemp, 2012). The aim of the present note is to determine whether or not it is possible to describe structural differences in fragments of single plates of placoderm armour, and whether or not these differences can be considered distinctive between species.

\section{Material and methods}

Ten plate fragments of arthrodiran placoderms (Denison, 1978) were collected from Lower Devonian (Emsian) argillaceous deposits in the Hamar Laghdad area in Morocco. This locality is situated approximately $16 \mathrm{~km}$ south of the city of Erfoud in the easternmost part of the Anti-Atlas mountains (Fig. 2). The Hamar Laghdad ridge is world-renowned for the occurrence of numerous conical Kess-Kess mud mounds which formed as a result of hydrothermal activity during the Emsian (inversus conodont Zone) (see Belka, 1998; Mounji et al., 1998). Kess-Kess mounds are mostly perfectly exhumed and have well exposed small caves and cavities - the outlets of venting chimneys. The mounds, as well as the caves and cavities, were subsequently filled in by argillaceous sediments that document the serotinus and patulus conodont

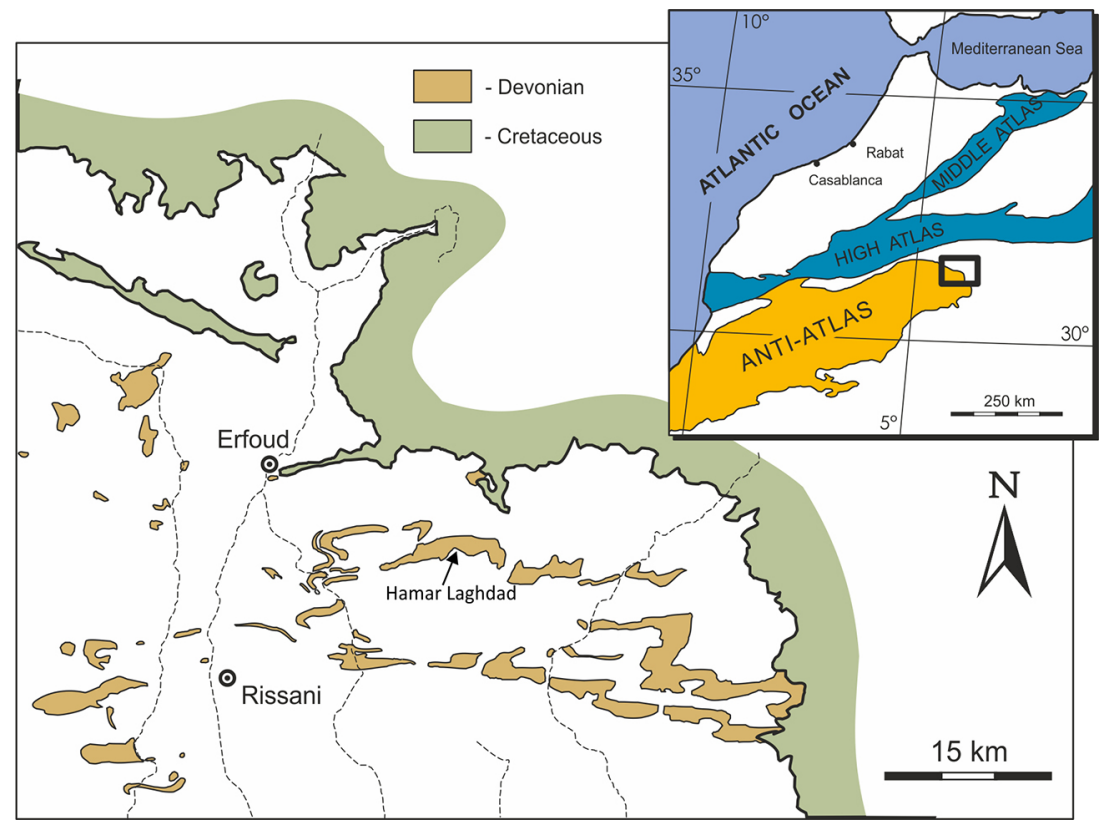

Fig. 2. Location of the Hamar Laghdad area in Morocco. 
zones by the end of the Emsian (Brachert et al., 1992; Aitken et al., 2002; Berkowski, 2008). These cover deposits are highly fossiliferous, especially close to the mounds. The fauna is very rich and diverse, containing mainly tabulate and rugose corals (Potthast \& Oekentorp, 1987; Plusquellec et al., 2004; Berkowski, 2008; Król et al., 2016), molluscs, crinoid ossicles (Berkowski \& Klug, 2012), brachiopods, phacopid trilobites (Klug et al., 2014) and placoderms. The last-named are discussed in the present paper.

Several characters of the bony plates, i.e., the shape, size and density of the nodules (elevated elements of sculpture) (Table 1), were compared in order to distinguish several morphotypes. Observations were made using a Zeiss SteREO Discovery V20 microscope with a Canon EOS 70D camera and a Hitachi S3000N scanning electron microscope under high vacuum. Specimens examined using SEM were coated with gold and palladium. SEM micrographs were taken at the Institute of Plant Protection (National Research Institute). All of the specimens studied are housed at the Institute of Geology of the Adam Mickiewicz University, Poznań.

Several specimens (HL3/1s/1, HL3/1s/7, HL3/1s/5 and HL3/1p/7) were cut parallel to natural margins, so that observations could be made in the direction of growth. Sections were made using a Unipress WS-20 wire-saw (wire diameter $0.05 \mathrm{~mm}$ ) to prepare thin sections for histological research.

\section{Results}

All specimens possess ornamentation in the form of distinct nodules that are surrounded by radial channels at the base. This typical sculpture, together with histological features, enables these specimens to be interpreted as remains of repre- sentatives of the Arthrodira (Szrek, 2012; Giles et al., 2013), a group of placoderms that predominated in Devonian seas and inhabited almost every ecological niche available to fishes at the time (Anderson \& Westneat, 2009; Rücklin et al., 2015; Olive et al., 2016).

Due to their doubtful systematic value, not all of the observed features were considered in the distinction of ornamentation morphotypes. Features such as the distance of the nodules from the edge of the plate overlap boundary (since the armour of Placodermi consisted of interconnected elements, some elements were tucked under adjacent plates, while others were superposed over adjacent elements) are related to the age of the individual (Trinjastic \& Hazelton, 2007). Density of the nodules, although also related to age, can be (together with other features) a taxonomic feature, which explains why it was included.

However, other features may reflect taxonomic differentiation. Ornamentation (nodules) might have had the same function as scale ornament has in some modern fishes, such as to create microcurrents and reduce drag (Kardong, 2002; Motta et al., 2012; Fletcher et al., 2014), but may vary in morphology.

Seven features described on micro- and nannoscales were considered as possibly taxonomic characters:

- Nodule size (diameter): small $(<0,4 \mathrm{~mm})(1)$, medium $(0,4-0,5 \mathrm{~mm})(2)$, large $(>0,5 \mathrm{~mm})(3)$;

- Nodule shape: round (1), oval (2), stellate (3), rectangular (4), triangle (5), other (6);

- Nodule density (number of nodules relative to surface area): low $(<22,2)(1)$, middle $(10-22,2)$ $(2)$, high $(>22,2)(3)$;

- Base of nodule diameter: small $(<1 \mathrm{~mm})(1)$, medium (1-1,2mm) (2), large (>1,2 mm) (3);

- Ratio of base diameter to nodule diameter: low $(<2,2)(1)$, medium $(2,2-2,4)(2)$, high $(>2,5)$ (3);

Table 1. Morphology of placoderm plates.

\begin{tabular}{lccccccc}
$\begin{array}{c}\text { Collection } \\
\text { number }\end{array}$ & $\begin{array}{c}\text { Nodule } \\
\text { size }\end{array}$ & $\begin{array}{c}\text { Nodule } \\
\text { shape }\end{array}$ & $\begin{array}{c}\text { Nodule } \\
\text { density }\end{array}$ & $\begin{array}{c}\text { Base of the } \\
\text { nodule }\end{array}$ & $\begin{array}{c}\text { Base/nodule } \\
\text { ratio }\end{array}$ & $\begin{array}{c}\text { Base } \\
\text { character }\end{array}$ & $\begin{array}{c}\text { Structure between } \\
\text { nodules }\end{array}$ \\
HL3/1s/5 & $2-3$ & 1 & 1 & 3 & 3 & 2 & 1 \\
HL3/1s/6 & 3 & 1 & 1 & 3 & $\times$ & $\times$ & 3 \\
HL3/1s/1 & 1 & 1 & 3 & 1 & 2 & 3 & 1 \\
HL3/1p/4 & $\times$ & 1 & $\times$ & $\times$ & $\times$ & $\times$ & 1 \\
HL3/1p/2 & 3 & 1 & $1-2$ & 3 & 3 & 2 & 1 \\
HL3/1p/7 & 3 & 1 & 3 & 2 & 1 & 2 & 1 \\
HL17/1s/1 & $2-3$ & 1 & 2 & 2 & 2 & 3 & 1 \\
HL3/1s/7 & $2-3$ & 1 & $1-2$ & 2 & 2 & $\times$ & 3 \\
HL3/1s/3 & 3 & 1 & 1 & 3 & $\times$ & $\times$ & 3 \\
\hline HL3/1p/3 & $\times$ & 1 & $\times$ & 2 & $\times$ & & \\
\hline
\end{tabular}




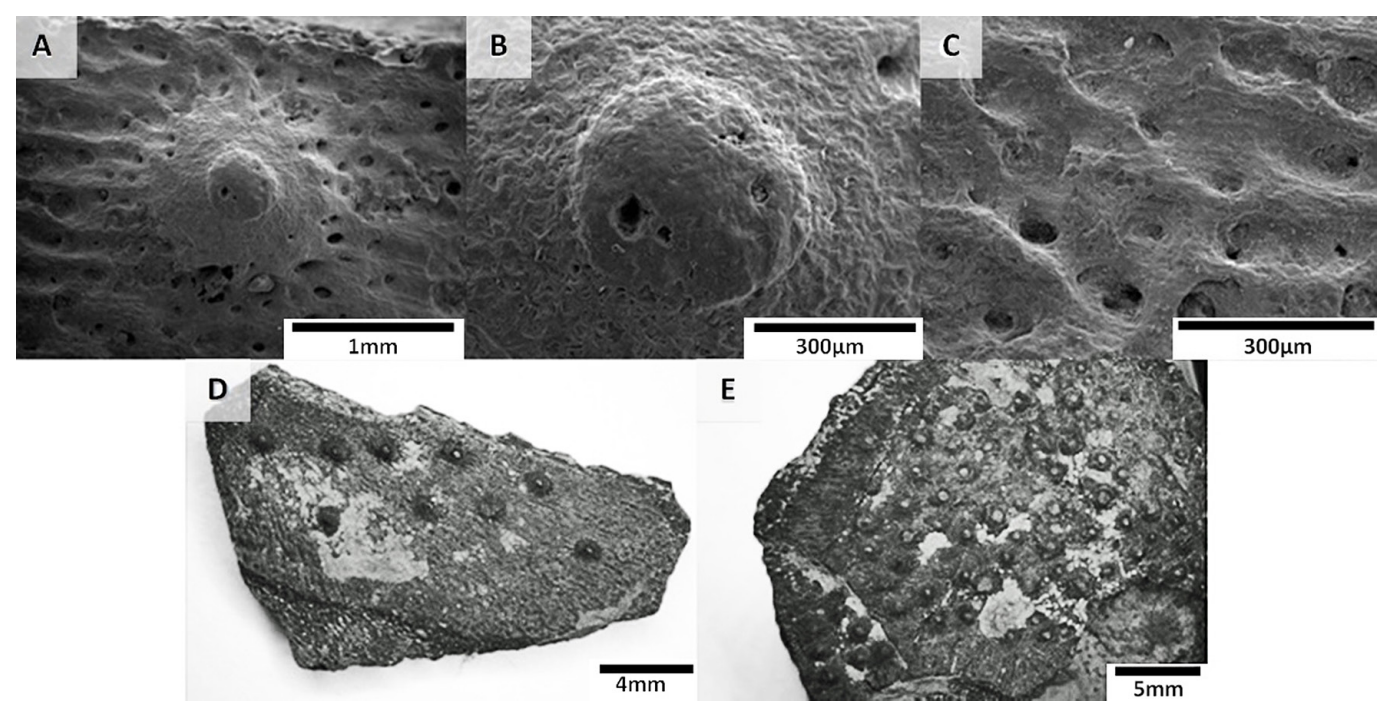

Fig. 3. Morphotype 1. A-D: HL3/1s/5; E: HL3/1p/2.

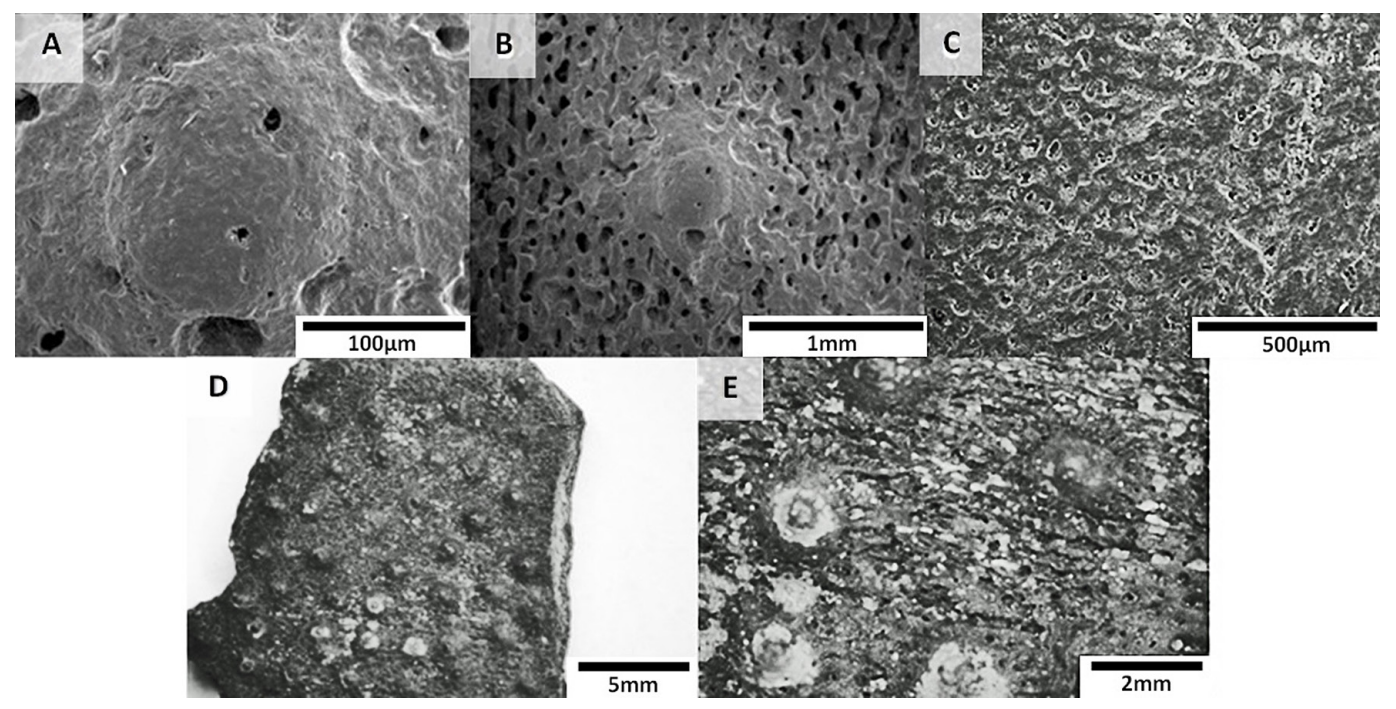

Fig. 4. Morphotype 2. A, B, D, E: HL3/1s/7; C: HL17/1s/1.

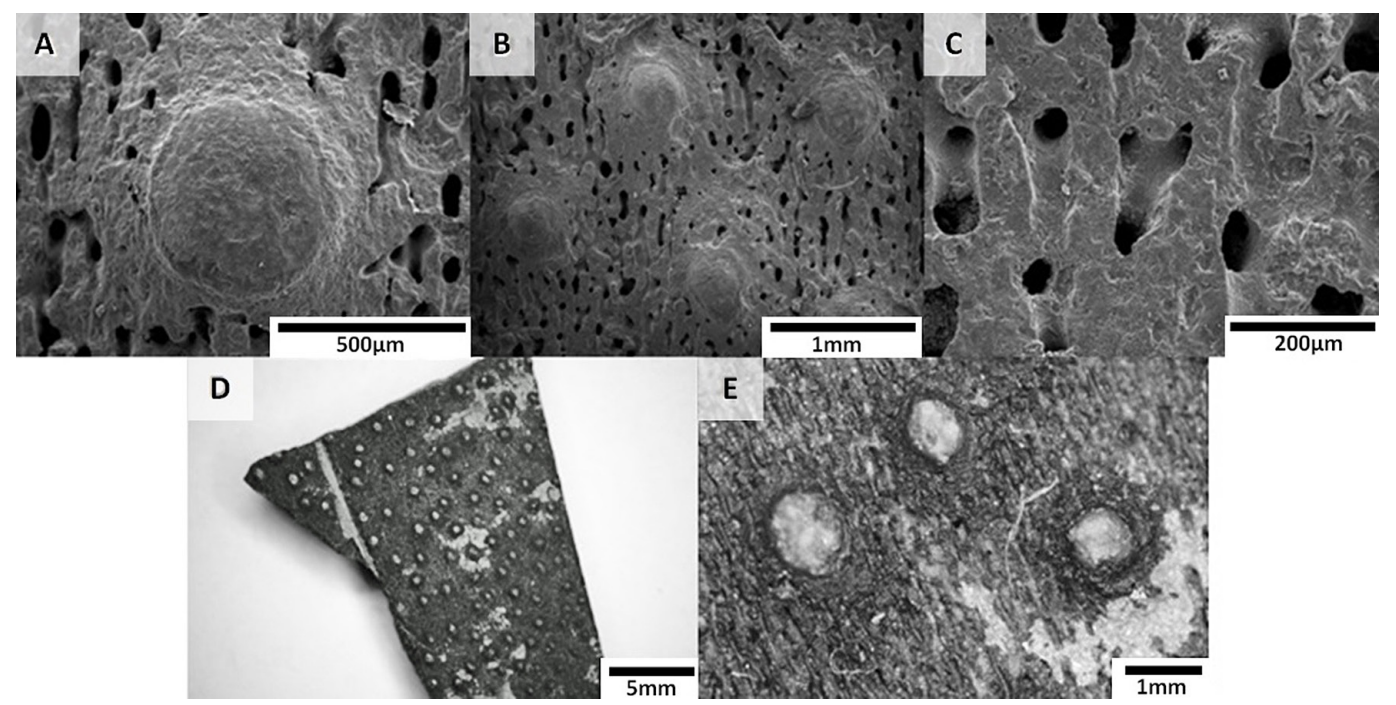

Fig. 5. Morphotype 3. HL3/1s/1. 


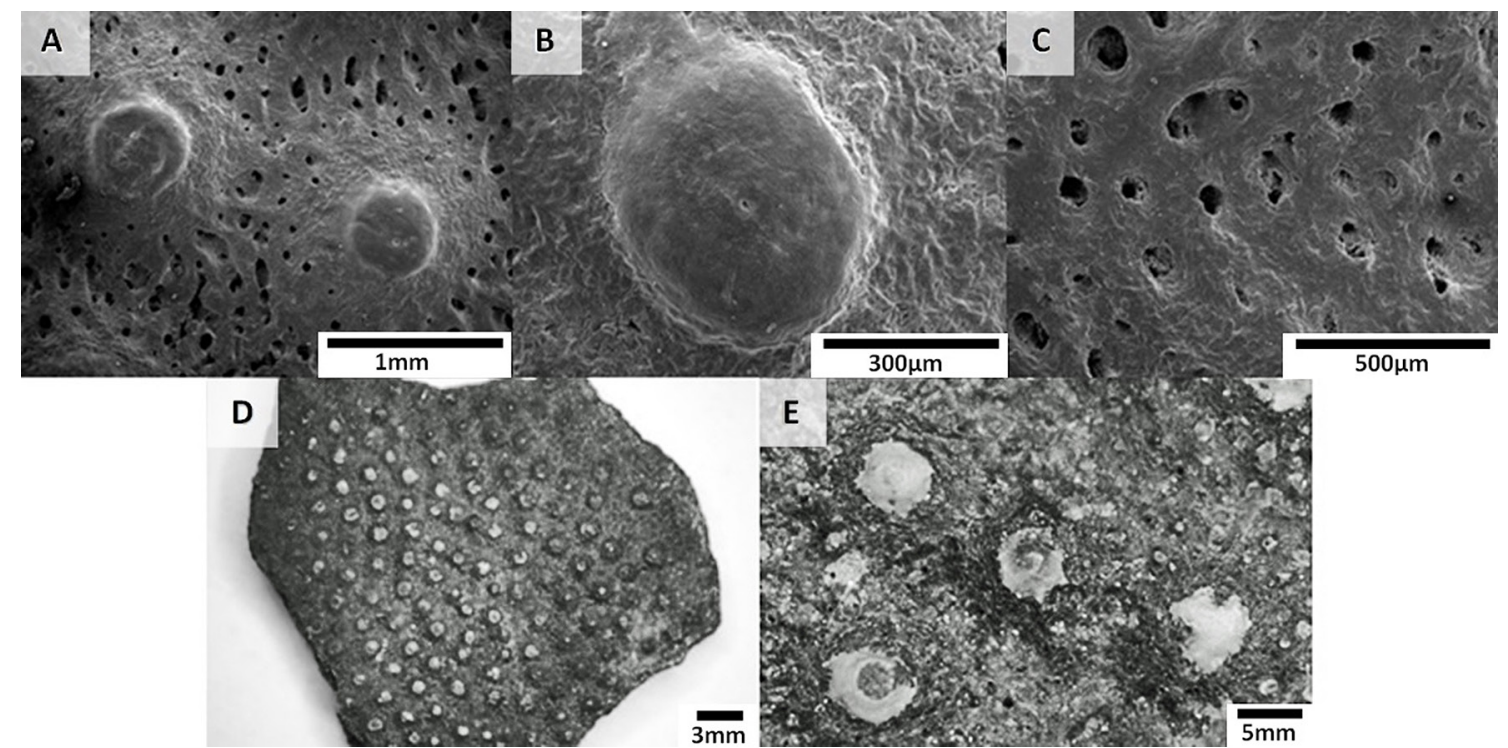

Fig. 6. Morphotype 4. HL3/1p/7.

- Base edge description: straight edge (1), tight undulation (2), wide undulation (3);

- Bone structure between nodules: spongiform (1), intermediate (2), smooth (3).

Features impossible to distinguish due to erosion or recrystallisation were marked with an $x$; the results are listed in Table 1 . Measurements were made using uneroded nodules or nodules with only a slightly worn dorsal surface, not affecting measurements of the diameter.

Individual specimens do not differ in the character of their nodules (shape or base of nodules) or the structure of the bone surface. However, the above-mentioned material does enable the differentiation of three distinct morphotypes (Table 2), which vary in nodule and base size and in nodule density (Figs. 3-5). There is a link between these features in that larger nodules are associated with lower densities. Specimen HL3/1p/7, representing morphotype 4, does not fit the trends described; this specimen possesses large nodules, a medium-size base, a low base/nodule diameter ratio, and a high nodule density (Fig. 6).

The histological samples (Fig. 7) do not reveal a variation that is as distinct as that which can be observed in the surface of the bones. Three of the specimens possess similar structures, consisting of three layers, with a lesser organised inner layer that is characterised by superposed laminae, a highly cancellar middle layer and a thin superficial layer. The pores are mostly parallel to the surface. The histological structure of HL3/1p/7 is slightly different from the others. The superficial layer is difficult to distinguish from the middle layer. The pores of the middle layer are smaller and often diagonal or irregular.

Table 2. Range of values of selected features of each morphotype.

\begin{tabular}{|c|c|c|c|c|c|c|}
\hline & $\begin{array}{c}\text { Nodules } \\
\text { diameter }[\mathrm{mm}]\end{array}$ & $\begin{array}{c}\text { Base of the } \\
\text { nodules } \\
\text { diameter }[\mathrm{mm}]\end{array}$ & $\begin{array}{l}\text { Base/Nodules } \\
\text { diameter ratio }\end{array}$ & $\begin{array}{l}\text { Nodules densi- } \\
\text { ty }\left[\text { nodule } / \mathrm{cm}^{2}\right]\end{array}$ & $\begin{array}{l}\text { Number of } \\
\text { foramens in } \\
\text { nodules }\end{array}$ & $\begin{array}{l}\text { Plate thickness } \\
{[\mathrm{mm}]}\end{array}$ \\
\hline $\begin{array}{l}\text { Morphotype } \\
\text { 1 HL3/1s/5, } \\
\text { HL3/1s/6, } \\
\text { HL3/1p/2, } \\
\text { HL3/1s/3 }\end{array}$ & $\begin{array}{c}\text { large } \\
0.48-0.56\end{array}$ & $\begin{array}{c}\text { large } \\
1.2-1.4\end{array}$ & $\begin{array}{l}\text { high } \\
2.5-2.56\end{array}$ & $\begin{array}{c}\text { low } \\
3.57-22.2\end{array}$ & $1-4$ & $\begin{array}{c}3 \\
1-3 \\
3-6 \\
6-7\end{array}$ \\
\hline $\begin{array}{l}\text { Morphotype } 2 \\
\text { HL17/1s/1, } \\
\text { HL3/1s/7 }\end{array}$ & $\begin{array}{l}\text { medium } \\
\sim 0.48\end{array}$ & $\begin{array}{l}\text { medium } \\
1.08-1.10\end{array}$ & $\begin{array}{l}\text { medium } \\
2.24-2.30\end{array}$ & $\begin{array}{l}\text { medium } \\
10.50-22.2\end{array}$ & $1-3$ & $\begin{array}{l}5 \\
2\end{array}$ \\
\hline $\begin{array}{l}\text { Morphotype } 3 \\
\text { HL3/1s/1 }\end{array}$ & $\begin{array}{c}\text { small } \\
0.37\end{array}$ & $\begin{array}{c}\text { small } \\
0.85\end{array}$ & $\begin{array}{l}\text { medium } \\
2.30\end{array}$ & $\begin{array}{l}\text { high } \\
38.55\end{array}$ & 0 & 5 \\
\hline $\begin{array}{l}\text { Morphotype } 4 \\
\text { HL3/1p/7 }\end{array}$ & $\begin{array}{l}\text { large } \\
0.54\end{array}$ & $\begin{array}{l}\text { medium } \\
1.13\end{array}$ & $\begin{array}{l}\text { low } \\
2.09\end{array}$ & $\begin{array}{l}\text { high } \\
31.08\end{array}$ & $1-2$ & 4 \\
\hline
\end{tabular}




\section{Discussion}

The uniform character of the nodules, the bone structure between them and the variations in nodule size and density can be explained in several ways.

1. All of the specimens belong to the same species; the variations in ornamentation are linked to different former locations of the plates on the fish body.

Variable sizes of nodules in a single specimen have been described in, for instance, Kiangyousteus yohii (Zhu \& Zhu, 2013). There are also species with unornamented body parts (Trinajstic \& Hazelton, 2007); however, only fully ornamented parts were considered in that study. In addition, plates representing different shapes (different parts of the body of the fish) can be grouped into one morphotype (e.g., HL3/1s/7 and HL3/1p/2), as can different size (thickness) of the plates assigned to one morphotype (Table 2).

2. The results show an ontogenetic sequence in which the surface of the bony plate grows more rapidly than the nodules, and new nodules do not appear during growth (i.e, the number of nodules is the same in juveniles and adults).

Multiple superposed layers form the lower cancellous zone in the dermal bones of placoderms (Burrow, 2005). The number of layers appears to increase with age of the fish (Gross, 1931). Based on this observation, all of the specimens are of approximately the same age (Fig. 7). However, new non-invasive tomography methods of analysis, such as the use of synchrotron (SRXTM) for detailed visualisation of tissue and structure types, shows that that is not necessarily true (Sanchez et al., 2012; Rücklin et al., 2014). The middle layer is often remodelled by resorption. While many of the canals, seen in cross section, are primary osteons, secondary osteons can be distinguished by the distortion of pre-existing fabric and the presence of a resorption line (Giles et al., 2013). While such remodelling is widespread among arthrodirans (Giles et al., 2013), SRXTM scans are the only tool which allows to trace the ontogeny of the specimen beyond doubt, as they reveal

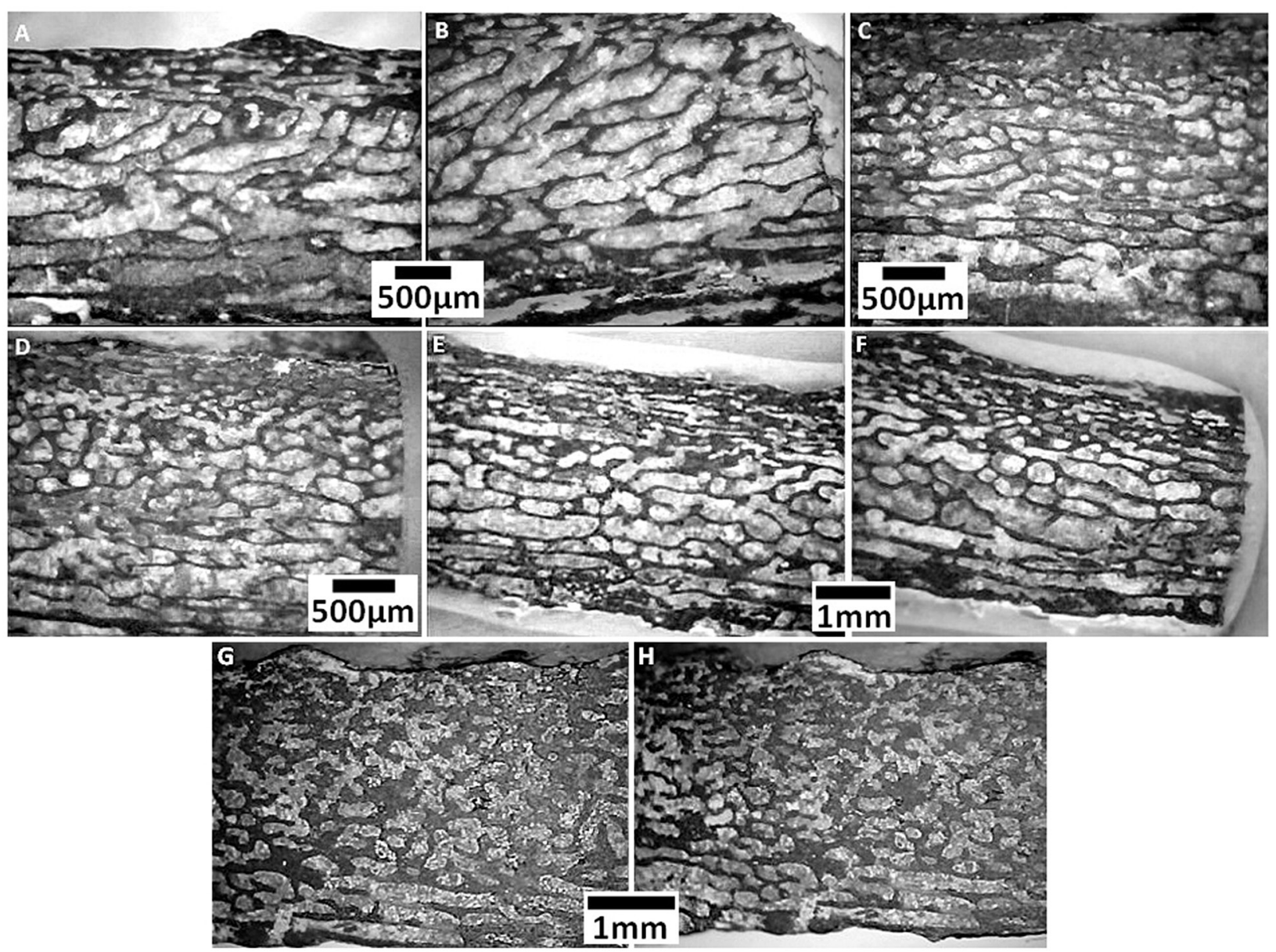

Fig. 7. Histology of specimens. A, B: HL3/1s/5; C, D: HL3/1s/7; E, F: HL3/1s/1; G, H: HL3/1p/7. 
LAGs as different grey scale values (reflecting mineralisation differences) (Rücklin et al., 2014). Morphotypes 1-3 are distinguished by differences in nodule size, base size and nodule density. It is well documented that juveniles of Compagopisicis have closely packed nodules, while in adults they are widely dispersed. This means that morphotypes 1-3 might reflect the ontogenetic sequence of a single species, with morphotype 3 representing a juvenile (high density of the nodules) specimen and morphotype 1 an adult (low density of the nodules). In this case, morphotype 4 could be the youngest specimen according to its histological character (i.e., superficial layer difficult to distinguish and middle layer pores more irregular) and high density of the nodules (Trinajstic \& Hazelton, 2007), but it probably represents a different species, because it possess larger nodules and the base of the nodules is of medium size (Table 2). The size of the plates should also be considered. Size and shape of the plates may differ between ontogenetic stages (Cloutier, 2010; Trinajstic \& Hazelton, 2007). Trinajstic \& McNamara (1999) described variation in allometry during ontogeny in Compagopiscis croucheri, thus showing that characters previously assumed to represent taxonomic distinctness between C. croucheri and Gogopiscis gracilis are in fact greatest morphological changes during ontogeny of a single species. Trinajstic \& Dennis-Bryan (2009) described a similar situation between Incisoculum richteri and Gogosteus sarahae, proving that they should be considered as single genus (I. richteri, I. sarahae).

In the Hamar Laghdad specimens different plate sizes (thickness) were assigned to one morphotype, with often distinct differences (1-7 $\mathrm{mm})$. Thin plates were associated with early on- togenetic stages for i.e., Asterolepis (Johanson \& Trinajstic, 2014). According to this, the morphotypes described do not group specimens of the same age or there are several species remains assigned to one morphotype. This is possible as the ornament of i.e. Compagopiscis, Eastmansoteus and Torostesus does not differ significantly, yet similar ornament does not mean the same size of the specimen (for instance, juvenile Dunkleosteus would be larger than adult Compagopiscis) (Trinajstic \& Hazelton, 2007; Carr, 2010).

3. Morphotypes resemble interspecific variation. In this case, the specimens described as morphotypes 1-3 are closely related (on the basis of the similar character of their ornamentation and histological structure; Giles et al., 2013), but constitute three different species (based on the variable size of the nodules, nodule bases and density of the nodules). Specimen HL3/1p/7, described as morphotype 4 , belongs to a more distantly related species, or (on the basis of its different histological character) represents a juvenile form of one of the three morphotypes mentioned, probably morphotype 1, judging from nodule size (Fig. 8). Coarser ornamentation distinguishes some species of closely related placoderms such as Bothriolepis (with more delicate sculpture), Pambulaspis and Asterolepis (more or less tuberculate) (Young, 1983). Similar differences can be observed between Lunapis and Macropetalichtys (Young, 1985). However, as mentioned above, some species might possess similar ornamentation. This means that, while morphotypes based on ornament represent at least three species (morphotypes 1-3), in fact more placoderm species in the Hamar Laghdad area might be represented.

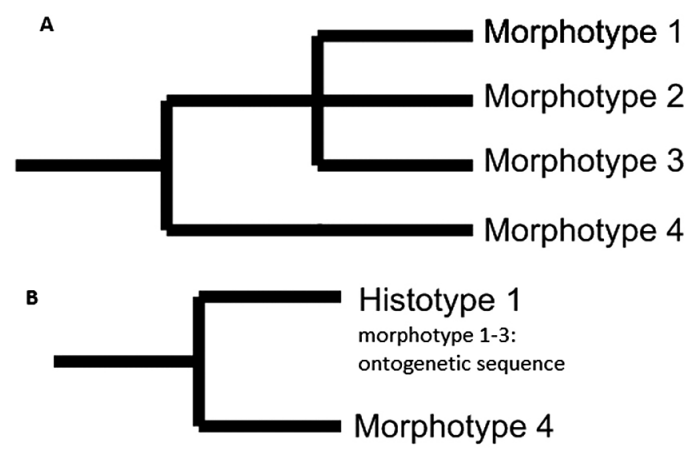

Fig. 8. Hypothetical phylogeny of Hamar Laghdad arthrodirans examined here. A - assuming taxonomic distinctness; $\mathrm{B}$ - assuming ontogenetic sequences; $\mathrm{C}$ - combining ontogeny and taxonomy (i.e., the most probable explanation).

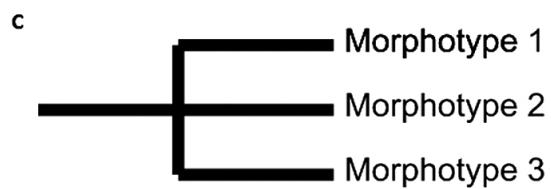

Morphotype 4

juvenile stage of morphotype 1? 


\section{Summary}

On the basis of ornamentation character, placoderm dermal plate fragments from the Hamar Laghdad area were grouped into four morphotypes. While plates representing different shapes could be grouped into a single morphotype, and only fully ornamented parts were considered, the variation is probably not connected with differences between body parts of the fish.

In view of the fact that characters such as nodule density were considered an ontogenetic explanation cannot be ruled out. To exclude this explanation a larger sample and complete specimens should be considered or non-invasive tomographic methods such as SRXTM scans should be used to trace LAGs and resorption in bones to characterise individual age of the specimens.

In view of the fact that in different morphotypes there are plates of the same thickness and number of layers in the lower cancellous zone, whereas in morphotype 4 there are specimens of distinct differences in thickness, the most probable explanation of the morphological variety for morphotypes $1-3$ is taxonomic diversity (similar to Antiarcha described by Young 1983, 1985). Based on its histological character, morphotype 4 might constitute the juvenile stage of one of these morphotypes. However, it cannot be excluded that one morphotype represents more than one species with similar ornament character and different size.

In conclusion, although it cannot be stated beyond doubt how many species the specimens described represent, it may be noted that ornamentation micro-observations can be used to distinguish placoderm species. In order to name these, complete specimens should be described and compared with the fragments analysed. To exclude ontogenetic changes SRXTM scans should be applied. Thus, analysis on a larger and more complete data set looks promising.

\section{Acknowledgements}

We wish to express sincere thanks to two anonymous reviewers, who kindly improved the language, added many important remarks and comments to an earlier version of the typescript. Material was collected during fieldwork in 2015, which was funded by the Polish National Science Centre, grant no. 2013/11/B/ST10/00243 to one of us (BB).

\section{References}

Aitken, S.A., Collom, C.J., Henderson, C.M. \& Johnston, P.A., 2002. Stratigraphy, paleoecology, and origin of Lower Devonian (Emsian) carbonate mud buildups, Hamar Laghdad, Eastern Anti-Atlas, Morocco, Africa. Bulletin of Canadian Petroleum Geology 50, 217-243.

Anderson, P.S.L. \& Westneat, M., 2009. A biomechanical model of feeding kinematics for Dunkleosteus terrelli (Arthrodira, Placodermi). Paleobiology 35, 251-269.

Belka, Z., 1998. Early Devonian Kess-Kess carbonate mud mounds of the Eastern Anti-Atlas (Morocco), and their relation to submarine hydrothermal venting. Journal of Sedimentary Research 68, 368-377.

Berkowski, B., 2008. Emsian deep-water Rugosa assemblages of Hamar Laghdad (Devonian, Anti-Atlas, Morocco). Palaeontographica Abteilung A 284, 17-68.

Berkowski, B. \& Klug, C., 2012. Lucky rugose corals on crinoid stems: unusual examples of subepidermal epizoans from the Devonian of Morocco. Lethaia 45, 24-33.

Brachert, T.C., Buggisch, W., Flügel, E., Hüssner, H.M., Joachimski, M.M., Tourneur, F. \& Walliser, O.H., 1992. Controls of mud mound formation: the Early Devonian Kess-Kess carbonates of the Hamar Laghdad, Antiatlas, Morocco. Geologische Rundchau 81, 15-44.

Brazeau, M.D. \& Friedman, M. 2015. The origin and early phylogenetic history of jawed vertebrates. Nature 520(7548), 490-497.

Burrow, C.J., 2005. Histological structure of cancellous bone layer in Bothriolepis canadensis (Antiarchi, Placodermi). Lethaia 38, 205-210.

Carr, R.K., 2010. Paleoecology of Dunkleosteus terrelli (Placodermi: Arthrodira). Kirtlandia 57, 36-45.

Cloutier, R., 2010. The fossil record of fish ontogenies: Insights into developmental patterns and processes. Seminars in Cell E Developmental Biology 21, 400-413.

Denison, R.H., 1978. Placodermi. Handbook of Palaeoichthyology vol. 2. Gustav Fischer, Stuttgart.129 pp.

Esmaeili, H.R. \& Gholami, Z., 2011. Scanning Electron Microscopy of the scale morphology in Cyprinid fish, Rutilus frisiikutum Kamenskii, 1901 (Actinopterygii: Cyprinidae). Iranian Journal of Fisheries Sciences 10,155-166.

Fletcher, T., Altringham, J., Peakall, J., Wignall, P. \& Dorrell R., 2014. Hydrodynamics of fossil fishes. Proceedings of the Royal Society B 271(1778), 1-9.

Giles, S., Rucklin, M. \& Gonoghue, P.C.J., 2013. Histology of "Placoderm" dermal skeletons: implications for the nature of the ancestral Gnathostome. Journal of Morphology 274, 627-644.

Gross, W., 1931. Asterolepis ornate Echw. und das Antiarchi-Problem. Palaeontographica 75, 1-62.

Janvier, P., 2007. The Devonian vertebrates of South America: Malvinokaffric Fishes and Gondwana-Euramerica faunal interchange. 4th European Meeting of the Palaeontology and Stratigraphy of Latin America. Cuadernos del Museo Geominero 8, 223-227.

Janvier, P., Tông-Dzuy, T., Phuong, T.H. \& DoànNhât, T., 1997. The Devonian vertebrates (Placodermi, Sarcopterygii) from Central Vietnam and their bearing 
on the Devonian palaeogeography of Southeast Asia. Journal of Asian Earth Sciences 15, 393-406.

Johanson, Z. \& Trinajstic, K., 2014. Fossilized ontogenies: the contribution of placoderm ontogeny to our understanding of the evolution of early gnathostomes. Palaeontology 57, 505-516.

Kardong., K.V., 2002. Vertebrates: Comparative Anatomy, Function, Evolution. $3^{\text {rd }}$ edition. McGraw-Hill, 762 pp.

Kaur, N. \& Dua, A., 2004. Species specifity as evidenced by scanning electron microscopy of fish scales. Current Science 87, 692-696.

Kemp, A., 2012. Formation and Structure of Scales in the Australian Lungifish, Neoceratodus forsteri (Osteichtyes: Dipnoi). Journal of Morphology 273, 530-540.

Klug, C., De Baets, K., Naglik, C.J. \& Waters, J., 2014. A new species of Tiaracrinus from the latest Emsian of Morocco and its phylogeny. Acta Palaeontologica Polonica 59, 135-145.

Król, J.J., Zapalski, M., Jakubowicz, M. \& Berkowski, B., 2016. Growth strategies of the tabulate coral Favosites bohemicus on unstable, soft substrates: An example from the Hamar Laghdad (Lower Devonian, Anti-Atlas, Morocco). Palaeogeography, Palaeoclimatology, Palaeoecology 449, 531-540.

Long, J.A. \& Daeschler, E.B., 2013. First articulated phyllolepid placoderm from North America, with comments on phyllolepid systematics. Proceedings of the Academy of Natural Sciences of Philadelphia 162, 33-46.

Long, J.A. \& Trinajstic, K., 2010. The Late Devonian Gogo Formation Lagerstatte of Western Australia: Exceptional Early Vertebrate Preservation and Diversity. Annual Review of Earth and Planetary Sciences 38, 255279.

Martin, R.A., 2009. Biology of sharks and rays. Anatomy. www-elasmo-research.org.[access: 23-02-2017].

Motta, P., Habegger, M.L., Lang, A., Hueter, R. \& Davis, J., 2012. Scale morphology and flexibility in the shortfin mako Isurus oxyrinchus and the blacktip shark Carcharhinus limbatus. Journal of Morphology 27, 1079-1198.

Mounji, D., Borque, P.A. \& Savard, M.M., 1998. Hydrothermal origin of Devonian conical mounds (KessKess) of Hamar Laghdad Ridge, Anti-Atlas, Morocco. Geology 26, 1123-1126.

Olive, S., Clément, G., Daeschler, E.B. \& Dupret, V., 2016. Placoderm Assemblage from the Tetrapod-Bearing Locality of Strud (Belgium, Upper Famennian) Provides Evidence for a Fish Nursery. Plos One, DOI: 10.1371/journal.pone.0161540

Patterson, R.T., Wright, C., Chang, A.S., Taylor, L.A., Lyons, P.D., Dallimore, A. \& Kumar, A., 2002. Atlas of common squamatological (fish scale) material in coastal British Columbia and an assessment of the utility of various scale types in paleofisheries reconstruction. Palaeontologia Electronica 4, 1-88.

Plusquellec, Y., Fernandez-Martinez, E.M., Mistiaen, B. \& Tourneur, F., 2004. Revision de Crenuliporadifformis Le Maitre, 1956 (Tabulata, Devonien du Nord Gondwana): morphologie, structure et microstructure. Revue de Paléobiologie 23, 181-208.
Potthast, I. \& Oekentorp, K., 1987. Eine FavositidenFaune aus dem Emsium/Eifelium des Hamar Laghdad, Tafilalt (SE-Marokko). Münstersche Forschungen zur Geologie und Palaeontologie 66, 57-94.

Ritchie, A., 2005. Cowralepis, a new genus of phyllolepid fish (Pisces, Placodermi) from the Late Middle Devonian of New South Wales, Australia. Proceeding of the Linnean Society of New South Wales 126, 215-259.

Rücklin, M., Donoghue, P.C.J., Cunningham, J.A., Marone, F. \& Stampanoni, M., 2014. Developmental paleobiology of the vertebrate skeleton. Journal of Paleontology 88, 676-683.

Rücklin, M., Long, J.A. \& Trinajstic, K., 2015. A new selenosteid arthrodire ('Placodermi') from the Late Devonian of Morocco. Journal of Vertebrate Palaeontology 35, e908896, DOI: 10.1080/02724634.2014.908896.

Sanchez, S., Alhberg, P.E., Trinajstic, K., Mirone, A. \& Tafforeau, P., 2012. Three-dimensional synchrotron virtual paleohistology: a new insight into the world of fossil bone microstructures. Microscopy and Microanalysis 18, 1095-1105.

Szrek, P., 2006. Skamieniałości Antiarcha (Vertebrata, Placodermi) w dewonie Gór Świętokrzyskich. Przegląd Geologiczny 54, 610-614.

Szrek, P., 2012. Placodermi. In: Ginter, M. (Ed.): Ryby Kopalne. Wydawnictwa Uniwersytetu Warszawskiego, Warszawa, 344 pp.

Trinajstic, K.M., 1999. Scale morphology of the Late Devonian palaeoniscoid Moythomasia durgaringa Gardiner and Bartram Alcheringa. An Australian Journal of Palaeontology 23, 9-19.

Trinajstic, K. \& Dennis-Bryan, K., 2009. Phenotypic plasticity, polymorphism and phylogeny within placoderms. Acta Zoologica 90, 83-102.

Trinajstic, K. \& Hazelton, M., 2007. Ontogeny, phenotypic variation and phylogenetic implications of arthrodires from the Gogo Formation, Western Australia. Journal of Vertebrate Paleontology 27, 571-583.

Trinajstic, K.M. \& McNamara, K.J., 1999. Heterochrony and phylogenetic trends. Records of the Western Australian Museum Supplement 57, 93-106.

Young, G.C., 1983. A new Antiarchan fish (Placodermi) from the Late Devonian of Southeastern Australia. BMR Journal of Australian Geology E Geophysics 8, 71-81.

Young, G.C., 1985. New discoveries of Devonian vertebrates from the Amadeus Basin, Central Australia. BMR Journal of Australian Geology E Geophysics 9, 239-254.

Zhu, Y.A. \& Zhu, M.A.,2013. Redescription of Kiangyousteus yohii (Arthrodira: Eubrachythoraci) from the Middle Devonian of China, with remarks on the systematics of the Eubrachythoraci. Zoological Journal of the Linnean Society169, 798-819. 